\title{
Isolation of Stem Cells, Endothelial Cells and Pericytes from Human Infantile Hemangioma
}

\author{
Lan Huang ${ }^{1,2}$ and Joyce Bischoff ${ }^{1,2, *}$
}

\author{
'Vascular Biology Program and Department of Surgery, Boston Children's Hospital, Boston, MA, USA; \\ ${ }^{2}$ Department of Surgery, Harvard Medical School, Boston, MA, USA \\ *For correspondence: joyce.bischoff@childrens.harvard.edu
}

\begin{abstract}
[Abstract] Infantile hemangioma $(\mathrm{IH})$ is a vascular tumor noted for its excessive blood vessel formation during infancy, glucose-transporter-1 (GLUT1)-positive staining of the blood vessels, and its slow spontaneous involution over several years in early childhood. For most children, IH poses no serious threat because it will eventually involute, but a subset can destroy facial structures and impair vision, breathing and feeding. To unravel the molecular mechanism(s) driving $\mathrm{IH}$-specific vascular overgrowth, which to date remains elusive, investigators have studied IH histopathology, the cellular constituents and mRNA expression. Hemangioma endothelial cells (HemEC) were first isolated from surgically removed IH specimens in 1982 by Mulliken and colleagues (Mulliken et al., 1982). Hemangioma stem cells (HemSC) were isolated in 2008, hemangioma pericytes in 2013 and GLUT1-positive HemEC in 2015. Indeed, as we describe here, it is possible to isolate HemSC, GLUT1-positive HemEC, GLUT1negative HemEC and HemPericytes from a single proliferating $\mathrm{IH}$ tissue specimen. This is accomplished by sequential selection using antibodies against specific cell surface markers: anti-CD133 to select HemSC, anti-GLUT1 and anti-CD31 to select HemECs and anti-PDGFR $\beta$ to select HemPericytes. IHderived cells proliferate well in culture and can be used for in vitro and in vivo vasculogenesis and angiogenesis assays.
\end{abstract}

Keywords: Hemangioma, Endothelial cells, Pericytes, Vascular tumor, Angiogenesis

[Background] IH occurs in 4-5\% of infants; it follows a unique life-cycle of rapid vascular growth, called the proliferating phase, followed by a slow spontaneous involuting phase (Leaute-Labreze et al., 2017). The proliferating phase contains immature vascular endothelial growth factor receptor-2 (VEGFR2)+ cells that appear to be in the process of vasculogenesis-the assembly of new vessels from stem/progenitor cells (Yu et al., 2004; Boscolo and Bischoff, 2009). The involuting phase begins after 12 months of age; well-defined vascular channels become evident yet little is known about mechanisms of involution except that endothelial apoptosis increases in the involuting phase (Mancini and Smoller 1996; Iwata et al., 1996; Razon et al., 1998). The residuum in the involuted phase is characterized by sparse vessels, adipocytes and connective tissue. This natural life-cycle of endothelial maturation and involution distinguishes $\mathrm{IH}$ from other vascular tumors and malformations, which do not regress and can grow at any time in a patient's life. In 2008 , we isolated a primitive mesenchymal cell from proliferating phase $\mathrm{IH}$ that can differentiate into endothelial cells, pericytes and adipocytes and form hemangiomalike (GLUT1-positive) vessels within 7 days after being implanted sub-cutaneously into immune-deficient mice (Khan et al., 2008). We designated these hemangioma stem cells (HemSC); subsequent studies 
validated HemSCs as the IH-initiating cell (Greenberger et al., 2010; Itinteang et al., 2011; Xu et al., 2011; Mai et al., 2013; Harbi et al., 2016; Edwards et al., 2017). Here we describe in detail how to isolate HemSC from proliferating phase $\mathrm{IH}$, and at the same time isolate GLUT1-positive HemEC, GLUT1negative HemEC and HemPericytes; this allows detailed studies on patient-derived cells that represent the vascular cellular constituents of $\mathrm{IH}$. In principal, the strategy could be broadly applied to other types of vascular tumors and vascular malformations, in particular isolation of endothelial cells from venous malformations (Goines et al., 2018), capillary malformations (Huang et al., 2017), arteriovenous malformations (Couto et al., 2017) and lymphatic malformations (Boscolo et al., 2015).

\section{Materials and Reagents}

1. Disposable scalpel

2. $15 \mathrm{ml}$ and $50 \mathrm{ml}$ sterile Falcon ${ }^{\circledR}$ conical tubes

3. $1.7 \mathrm{ml}$ sterile microcentrifuge tube

4. Tissue culture-treated 24-well and 6-well plates

5. Falcon ${ }^{\circledR} 100 \mu \mathrm{m}$ Cell Strainer (Corning, catalog number: 352360 )

6. Pre-Separation Filters $(70 \mu \mathrm{m})$ (Miltenyi Biotec catalog number: 130-095-823)

7. Nalgene Rapid-Flow disposable Filter Units with PES (polyethersulfone) membrane, $0.2 \mu \mathrm{m}$ (Thermo Scientific, catalog number: 564-0020)

8. MS Columns (Miltenyi Biotec, catalog number: 130-042-201)

9. Dynabeads ${ }^{\mathrm{TM}}$ CD31 Endothelial Cell, human (Thermo Fisher, catalog number: 11155D)

10. Liberase ${ }^{\mathrm{TM}}$ (Roche, catalog number: 5401119001$)$

11. Dispase (Corning, catalog number: 354235 )

12. Fetal Bovine Serum (HyClone, catalog number: SH30396.03)

13. $\mathrm{EGM}^{\mathrm{TM}}$-2 Endothelial Cell Growth Medium-2 BulletKit ${ }^{\mathrm{TM}}$ (Lonza, catalog number: CC-3162)

14. DMEM, high glucose, GlutaMAX ${ }^{\mathrm{TM}}$ Supplement (Thermo Fisher, catalog number: 10566-016)

15. Fibronectin (FN) (Chemicon, catalog number: FC010; stock= $1 \mu \mathrm{g} / \mu \mathrm{l}$ )

16. Phosphate buffered saline (PBS) 10x, without calcium and magnesium (Lonza, catalog number: 17-517Q)

17. 100x GPS (L-Glutamine-Penicillin-Streptomycin, Corning, catalog number: $30-009-\mathrm{Cl}$ )

18. $0.05 \%$ Trypsin $0.53 \mathrm{mM}$ EDTA, $1 x$ (Corning, catalog number: $25-052-\mathrm{Cl}$ )

19. Red blood cell lysis buffer (Roche, catalog number: 11814389001)

20. FcR Blocking Reagent, human (Miltenyi Biotec, catalog number: 130-059-901)

21. CD133 MicroBead Kit (Miltenyi Biotec, catalog number: 130-050-801)

22. Dynabeads ${ }^{\mathrm{TM}}$ Pan Mouse IgG (Thermo Fisher, catalog number: 11041)

23. Dynabeads ${ }^{\circledR}$ M-270 Streptavidin (Thermo Fisher, catalog number: 65305)

24. Human GLUT1 Antibody (R\&D Systems, catalog number: MAB1418)

25. Human PDGFR $\beta$ Biotinylated Antibody (R\&D Systems, catalog number: BAF385)

26. $\mathrm{CaCl}_{2} \cdot 2 \mathrm{H}_{2} \mathrm{O}$ 
27. $\mathrm{MgSO}_{4} \cdot 7 \mathrm{H}_{2} \mathrm{O}$

28. Glucose

29. Sodium citrate

30. Citric acid

31. BSA

32. $\mathrm{Na}_{2} \mathrm{CO}_{3}$

33. DMSO

34. Heat inactivated FBS (hiFBS) (see Recipes)

35. Liberase ${ }^{\mathrm{TM}}$ stock $(0.5 \mathrm{mg} / \mathrm{ml})$ (see Recipes)

36. Dispase stock (50 U/ml, $100 \mathrm{ml}$ ) (see Recipes)

37. 10x Calcium and Magnesium $\left(\mathrm{Ca}^{2+} / \mathrm{Mg}^{2+}\right)$ solution (see Recipes)

38. Collection Medium (see Recipes)

39. Digestion Buffer (see Recipes)

40. 6\% Citrate Dextrose Solution, Solution A (ACD-A) (see Recipes)

41. Buffer $A$ (see Recipes)

42. Buffer $B$ (see Recipes)

43. EGM-2 medium (see Recipes)

44. Fibronectin (FN)-coating buffer (see Recipes)

45. Coating culture plates with fibronectin (FN) (see Recipes)

46. Quenching/Thawing medium (see Recipes)

47. Freezing medium (see Recipes)

\section{Equipment}

1. Forcep

2. Pipettes

3. Pestle (Thomas Scientific, catalog number: 3431D94; the smooth pestle is $44 \mathrm{~mm} \times 22 \mathrm{~mm}$ )

4. Refrigerator

5. Centrifuge (Eppendorf, model: 5804)

6. Water Bath (Fisher Scientific, model: 2223)

7. MiniMACS Separator (Miltenyi Biotec, catalog number: 130-042-102)

8. DynaMag ${ }^{\mathrm{TM}}-2$ Magnet (Thermo Fisher, catalog number: 12321D)

9. $-80^{\circ} \mathrm{C}$ freezer

10. $-20^{\circ} \mathrm{C}$ non-defrost freezer 


\section{Procedure}

IH specimens should be obtained under an institutional review board (IRB)-approved human subject protocol. The clinical diagnosis should be confirmed by histopathology. Biosafety Level 2 procedures for working with human tissue should be followed. Sterile technique and sterile solutions should be used at each step of tissue homogenization, antibody-mediated selection and cell culture.

A. Tissue collection and digestion

1. Transfer $\mathrm{IH}$ tissue into a sterile container filled with $5-10 \mathrm{ml}$ Collection Medium as soon as possible after resection. Place the tissue on ice and bring it to the lab.

2. Rinse the tissue twice with sterile PBS to remove surface blood.

3. If necessary, use a sterile scalpel and forcep to separate the inner soft IH tissue from the outer rough epidermis.

4. Mince the $\mathrm{IH}$ tissue into $\sim 2 \mathrm{~mm}^{3}$ pieces with a sterile, disposable scalpel.

5. Transfer minced $\mathrm{IH}$ tissue into a $50 \mathrm{ml}$ conical tube and mix with freshly-made Digestion Buffer using gentle pipetting. Use 5 volumes of Digestion Buffer per gram of tumor tissue (i.e., $5 \mathrm{ml}$ Digestion Buffer/1 gram of minced IH).

6. Incubate mixture at $37^{\circ} \mathrm{C}$. Mix every 5-10 min by tapping the tube. The tissue should appear soft and the solution should become turbid after 40-50 min. Do not over-digest (i.e., longer than $1 \mathrm{~h}$ ) because the sample will become viscous due to cell lysis and DNA release.

7. Gently homogenize the $\mathrm{IH}$ tissue digest with a Teflon pestle. Move pestle up and down and twist while squeezing the $50 \mathrm{ml}$ tube. Let tumor pieces settle to the bottom of tube and transfer the supernatant to a new tube on ice.

8. Add $5 \mathrm{ml}$ Collection Medium to the remaining tissue in the original tube and repeat the homogenization; repeat once more. Combine the three supernatants.

9. Filter the combined supernatants through a $100 \mu \mathrm{m}$ sterile cell strainer.

10. Wash cell strainer with $5-10 \mathrm{ml}$ Collection Medium to flush cells through the strainer.

11. Centrifuge cell suspension at $282 \times \mathrm{g}$, room temperature (RT) for $5 \mathrm{~min}$.

12. Carefully aspirate supernatant and re-suspend the cell pellet with 5-10 $\mathrm{ml}$ Buffer $A$.

13. Centrifuge cell suspension at $240 \times \mathrm{g}$, RT for $5 \mathrm{~min}$. Aspirate the supernatant carefully.

14. Optional: Lysis of red blood cells (RBCs) for the very red (i.e., blood filled) specimen

a. Resuspend cells in $1 \mathrm{ml}$ PBS and mix well with $7 \mathrm{ml}$ ice-cold RBC lysis buffer.

b. Incubate at $4{ }^{\circ} \mathrm{C}$ for 10 min with gentle shaking.

c. Centrifuge at $240 \times \mathrm{g}$, RT for $5 \mathrm{~min}$. Aspirate the supernatant.

15. Resuspend the cell pellet in $1 \mathrm{ml}$ Buffer $A$. Determine cell number. Expect $1 \times 10^{6}-2 \times 10^{6}$ cells from $0.5 \mathrm{~cm}^{3} \mathrm{IH}$ specimen. Use half of the cells for HemSC Purification (Procedure B) and the other for HemEC and HemPericyte Purification (Procedures C-E). See Figure 1 for a schematic of the cell purification strategy. 


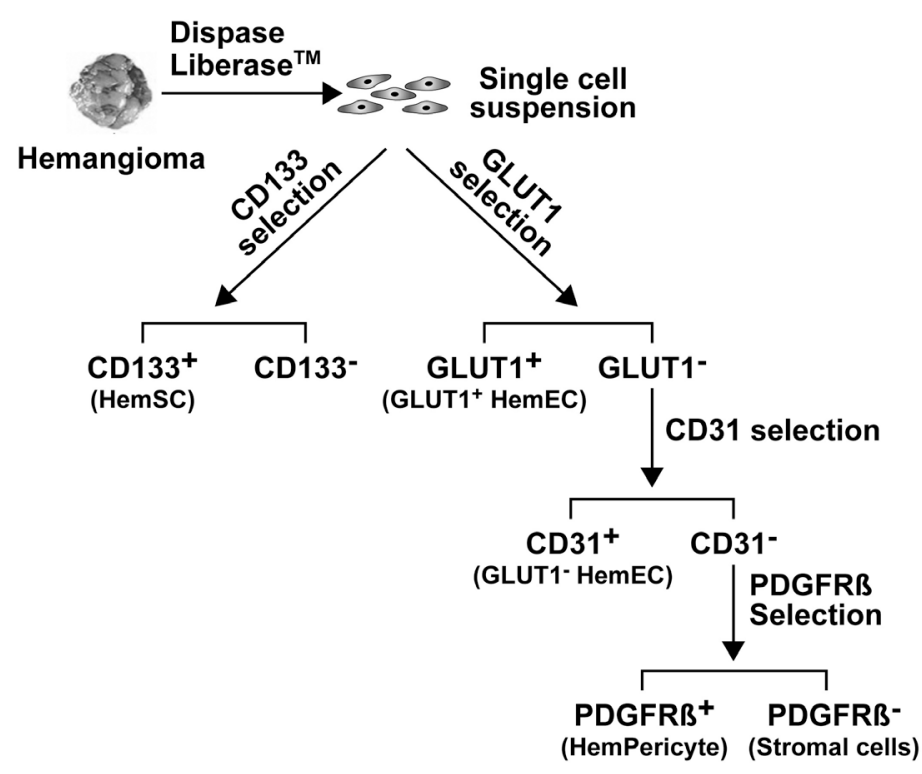

Figure 1. Cell isolation using sequential antibody-coated magnetic beads. Schematic shows work flow for isolating four cell types from IH tissue.

B. HemSC purification (see Miltenyi Biotec protocol for the additional information)

1. Centrifuge cell suspension at $240 \times g$, RT for $5 \mathrm{~min}$. Aspirate supernatant.

2. Resuspend the cells in $300 \mu$ ice-cold Buffer $A$.

3. Add $100 \mu \mathrm{l}$ human FcR blocking reagent, mix well by pipetting up and down 2-3 times.

4. Add $100 \mu \mathrm{l} \mathrm{CD133} \mathrm{Microbeads,} \mathrm{mix} \mathrm{well.}$

5. Incubate for $30 \mathrm{~min}$ in the refrigerator $\left(2-8^{\circ} \mathrm{C}\right)$, gently tap tube every 5-10 $\mathrm{min}$.

6. Wash cells by adding $9.5 \mathrm{ml}$ ice-cold Buffer $\mathrm{A}$.

7. Centrifuge cells at $240 \times \mathrm{g}, \mathrm{RT}$ for $5 \mathrm{~min}$. Aspirate supernatant.

8. Resuspend cells in $500 \mu \mathrm{l}$ ice-cold Buffer A.

9. Pre-wash MS column by placing the MS column in the magnetic field and rinsing with $500 \mu \mathrm{l}$ Buffer A. Wait until the column reservoir is empty.

10. Place a $70 \mu \mathrm{m}$ cell strainer on the top of column reservoir. Load cell suspension and let it run through cell strainer and enter MS column held in the magnet.

11. Collect the effluent.

12. Wash the MS column with $4 \times 500 \mu$ l Buffer A.

13. Collect all effluent fractions and combine together; save as CD133-negative cells.

14. Remove the column from the magnetic separator and place it on a $1.7 \mathrm{ml}$ sterile microcentrifuge tube.

15. Pipette $1 \mathrm{ml}$ Buffer $A$ onto the top of column and collect CD133-positive cells by firmly pushing the plunger (supplied) into the column.

16. Optional: To increase the purity of $C D 133$-positive cells, load the released cell fraction over a second MS column and repeat CD133 selection. 
17. Determine the number of cells in both CD133-positive and CD133-negative cell fractions. Centrifuge cell suspensions at $240 \times \mathrm{g}$, RT for $5 \mathrm{~min}$. Remove supernatant. The number of CD133+ cells varies from $0.2 \%$ to $2 \%$ of total digested tumor cells, as reported by Yu et al., 2004. The yield depends on the size of the specimen, the enzyme digestion and batch of antiCD133-coated beads.

18. Resuspend CD133-positive cells in $1 \mathrm{ml}$ EGM-2 media. Plate them in one-well of 24-well plate pre-coated with $1 \mu \mathrm{g} / \mathrm{cm}^{2} \mathrm{FN}$. The CD133-positive HemSC will start to grow rapidly in culture after 7-10 days and will exhibit a mesenchymal morphology (Figure 3) (Khan et al., 2008).

19. Plate CD133-negative cells in one well of 6 -well plate pre-coated with $1 \mu \mathrm{g} / \mathrm{cm}^{2} \mathrm{FN}$. After primary culture, cryopreserve cells for future use (Procedure $H$ ), for example the CD133-negative fraction can be used for selection of $\mathrm{CD} 31^{+}$and/or PDGFR $\beta^{+}$cells.

C. GLUT1-positive endothelial cell purification (see Pan mouse IgG Dynabeads protocol for the additional information)

1. Centrifuge the other half of cell suspension at $240 \times g$, RT for 5 min.

2. Resuspend cells (up to $10^{6}$ ) in $80 \mu$ ice-cold Buffer $A$.

3. Add $20 \mu \mathrm{l}$ human FcR blocking reagent.

4. Incubate for $10 \mathrm{~min}$ in the refrigerator $\left(2-8{ }^{\circ} \mathrm{C}\right)$.

5. Add $1 \mu \mathrm{g}$ of mouse anti-human GLUT1 antibody to $100 \mu \mathrm{l}$ cell suspension-1 $\mu \mathrm{g}$ antibody $/ 10^{6}$ cells $/ 100 \mu \mathrm{l}$ buffer.

6. Incubate for $30 \mathrm{~min}$ in the refrigerator $\left(2-8^{\circ} \mathrm{C}\right)$. Mix by gently tapping the tube every $5-10 \mathrm{~min}$.

7. Add $10 \mathrm{ml}$ ice-cold Buffer $\mathrm{A}$, mix well.

8. Centrifuge at $240 \times \mathrm{g}$, RT for $5 \mathrm{~min}$. Resuspend the cell pellet in $100 \mu \mathrm{l}$ ice-cold Buffer $\mathrm{B}$.

9. Pre-wash Dynabeads: Transfer $5 \mu$ of the Pan mouse IgG Dynabeads to a $1.7 \mathrm{ml}$ sterile microcentrifuge tube. Add $1 \mathrm{ml}$ ice-cold Buffer $B$ and mix. Place the tube in a magnet for $1 \mathrm{~min}$ and aspirate supernatant.

10. Remove the tube from the magnet and resuspend the washed Dynabeads with $5 \mu \mathrm{l}$ ice-cold Buffer B.

11. Add washed beads to anti-GLUT1 treated cells at $1.5 \mu \mathrm{l}$ beads $/ 10^{6}$ cells $/ 100 \mu \mathrm{l}$ buffer. Mix well and incubate for $10 \mathrm{~min}$ in the refrigerator $\left(2-8^{\circ} \mathrm{C}\right)$. The bead to cell ratio can be increased to $2.5 \mu \mathrm{l}$ beads $/ 10^{6}$ cells $/ 100 \mu \mathrm{l}$ buffer but avoid increasing the incubation time because this may increase non-specific binding.

12. Add $1 \mathrm{ml}$ ice-cold Buffer B. Place the tube in the magnet for $1 \mathrm{~min}$. Anti-GLUT1-bound cells will move towards the magnet leaving the GLUT1-negative cells free in suspension. Gently collect the GLUT1-negative cell fraction into a new $15 \mathrm{ml}$ conical tube.

13. Remove the tube from the magnet. Add $1 \mathrm{ml}$ ice-cold buffer $B$ and mix well. Place the tube back to the magnet, collect and combine the un-bound cells in the same $15 \mathrm{ml}$ tube.

14. Repeat this wash step twice more. 
15. After the final wash, remove the tube from the magnet to release the bead-bound GLUT1positive cells by adding $1 \mathrm{ml}$ EGM-2 media to resuspend cells. Determine the cell number. Plate cells in one well of 24-well plate precoated with $1 \mu \mathrm{g} / \mathrm{cm}^{2} \mathrm{FN}$.

16. The GLUT1-negative cells will be further purified using anti-CD31 magnetic beads selection as described in the next section.

Optional: To increase the yield of GLUT1-positive cells, a second round of anti-mouse IgG beads selection can be applied in GLUT1-negative cell fraction. Repeat magnetic separation and plate cells in a new well of 24-well plate. Do not combine cells from the 1st selection. The GLUT1positive endothelial cells will start to proliferate after 10-12 days in culture (Huang et al., 2015). Note: Almost all of GLUT1-positive cells in proliferating IH are endothelial cells (see Huang et al., 2015 Figure 1C), that is, they express endothelial markers CD31, VE-Cadherin and VEGRR2. After 2-3 weeks in vitro culture and expansion, the cells transition to a mesenchymal phenotype (Figure 3) (Huang et al., 2015).

D. GLUT1-negative endothelial cells purification (see anti-human CD31 Dynabeads protocol for the additional information)

1. Determine the number of cells in the GLUT1-negative fraction. Centrifuge cell suspension at $240 \times \mathrm{g}$, RT for $5 \mathrm{~min}$. Aspirate the supernatant.

2. Resuspend the cells in $200 \mu$ ice-cold buffer $B$.

3. Pre-wash Dynabeads: Transfer $5 \mu \mathrm{l}$ anti-human CD31 Dynabeads to a $1.7 \mathrm{ml}$ sterile microcentrifuge tube. Add $1 \mathrm{ml}$ ice-cold Buffer $\mathrm{B}$ and mix. Place the tube in a magnet for $1 \mathrm{~min}$ and aspirate supernatant.

4. Remove the tube from the magnet and resuspend washed beads with $5 \mu$ ice-cold Buffer B Add $2 \mu \mathrm{l}$ washed anti-human CD31 Dynabeads to the cells and incubate for $10 \mathrm{~min}$ in the refrigerator $\left(2-8^{\circ} \mathrm{C}\right)$.

Note: 5-8 beads per cell is optimal for selection (Figure 2). If too many beads bind, it will reduce endothelial cell attachment to the FN-coated dish. Do not incubate for longer than 10 min as this might result in non-specific binding and decreased purity.

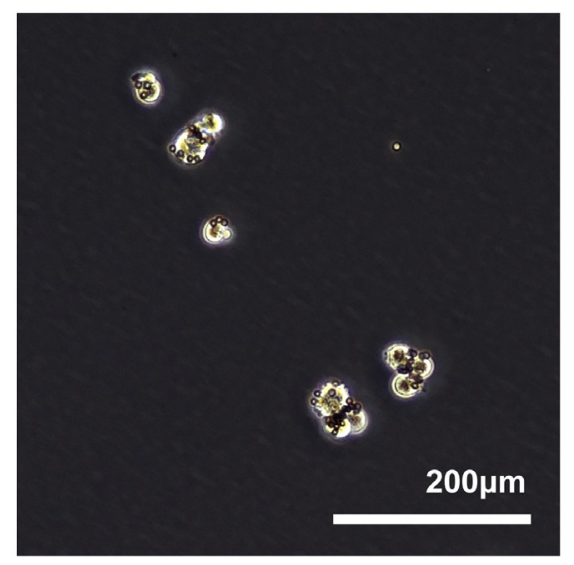

Figure 2. Anti-CD31-bead bound cells 
5. Add $1 \mathrm{ml}$ ice-cold Buffer B. Place the tube in the magnet and hold for $1 \mathrm{~min}$. Anti-CD31 Dynabead bound cells will move towards the magnet (accumulating on the wall of the tube) leaving the unbound cells, the CD31-negative cell fraction, free in suspension. Gently collect the CD31-negative cell fraction into a new $15 \mathrm{ml}$ conical tube.

6. Remove the tube from the magnet. Add $1 \mathrm{ml}$ ice-cold buffer $B$ and mix well. Repeat magnetic separation. Collect and combined bead un-bound cells into the same $15 \mathrm{ml}$ tube.

7. Repeat wash step two more times.

8. After the final wash, remove the tube from the magnet and release the bead-bound CD31positive cells in $1 \mathrm{ml} \mathrm{EGM-2} \mathrm{media} \mathrm{(Figure} \mathrm{2).} \mathrm{Determine} \mathrm{the} \mathrm{cell} \mathrm{number} \mathrm{and} \mathrm{plate} \mathrm{cells} \mathrm{in} \mathrm{one}$ well of 24-well plate precoated with $1 \mu \mathrm{g} / \mathrm{cm}^{2} \mathrm{FN}$.

9. GLUT1-negative HemECs will require 7-10 days to begin rapid proliferation. If needed, repeat the anti-CD31 selection to increase the endothelial cell purity. GLUT1-negative HemEC show typical endothelial morphology (Figure 3).

Optional: To increase the yield of CD31-positive cells, a second round of anti-CD31 beads selection can be applied in the CD31-negative cell fraction. Repeat magnetic separation and plate cells in a new well of 24-well plate. Do not combine cells from the first selection.

HemsC

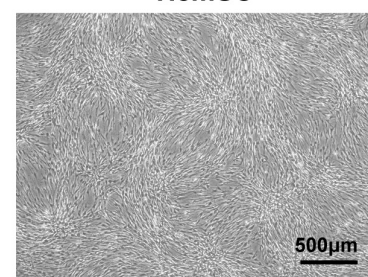

GLUT1+ HemEC

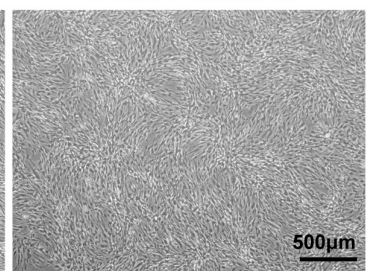

GLUT1- HemEC

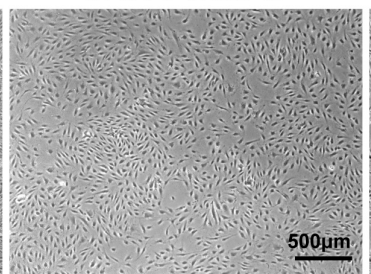

HemPericyte

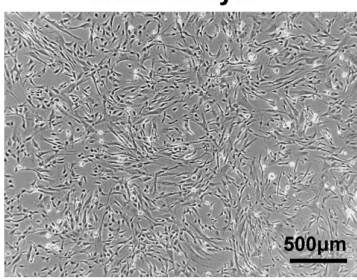

Figure 3. IH cells in the primary culture

E. PDGFRß-positive cell purification (see Dynabeads ${ }^{\circledR}$ M-270 Streptavidin protocol for the additional information)

1. Determine the number of cells in the CD31-negative cell fraction. Centrifuge the cell suspension at $240 \times \mathrm{g}$, RT for $5 \mathrm{~min}$. Aspirate the supernatant.

2. Resuspend the cells in $80 \mu \mathrm{l}$ ice-cold buffer $A$.

3. Add $20 \mu \mathrm{l}$ human FcR blocking reagent.

4. Incubate for $10 \mathrm{~min}$ in the refrigerator $\left(2-8^{\circ} \mathrm{C}\right)$.

5. Add $1 \mu \mathrm{g}$ of biotinylated anti-PDGFR $\beta$ antibody to the $100 \mu \mathrm{l}$ cell suspension.

6. Incubate for $30 \mathrm{~min}$ in the refrigerator $\left(2-8^{\circ} \mathrm{C}\right)$. Mix by gently tapping tube every $5-10 \mathrm{~min}$.

7. Add $10 \mathrm{ml}$ ice-cold buffer $\mathrm{A}$, mix well.

8. Centrifuge cell suspension at $240 \times g$, RT for $5 \mathrm{~min}$. Aspirate supernatant and resuspend cells in $100 \mu \mathrm{l}$ ice-cold Buffer B. 
9. Pre-wash Dynabeads: Transfer $5 \mu \mathrm{l}$ Streptavidin-coupled Dynabeads to a $1.7 \mathrm{ml}$ microcentrifuge tube. Add $1 \mathrm{ml}$ ice-cold Buffer $B$ and mix. Place the tube in a magnet for $1 \mathrm{~min}$ and aspirate supernatant. Remove the tube from the magnet and resuspend the washed beads with $5 \mu$ icecold Buffer B.

10. Add $1.5 \mu \mathrm{l}$ washed Streptavidin-coupled Dynabeads to the cells, mix well and incubate for 10 min in the refrigerator $\left(2-8^{\circ} \mathrm{C}\right)$.

11. Add $1 \mathrm{ml}$ ice-cold Buffer B. Place the tube in the magnet for $1 \mathrm{~min}$. PDGFRß-positive cells will move towards the magnet leaving the PDGFR $\beta$-negative cell fraction free in suspension. Gently collect the PDGFR $\beta$-negative cell fraction into a new $15 \mathrm{ml}$ conical tube.

12. Remove the tube from the magnetic field. Add $1 \mathrm{ml}$ ice-cold buffer $B$ and mix gently by pipetting. Place the tube back to the magnet, collect and combine the un-bound cells in the same $15 \mathrm{ml}$ tube.

13. Repeat wash step two more times, collect and combine PDGFRß-negative cells.

14. After the final wash, collect PDGFRß-positive cells in $1 \mathrm{ml}$ EGM-2 media, determine cell number and plate into one well of 24-well plate precoated with $1 \mu \mathrm{g} / \mathrm{cm}^{2} \mathrm{FN}$.

Note: PDGFRß-positive cells-HemPericytes-will start to expand after 5-7 days (Figure 3).

15. Determine the number of PDGFR $\beta$-negative cells. Plate cells into one well of 6-well plate precoated with $1 \mu \mathrm{g} / \mathrm{cm}^{2} \mathrm{FN}$ and filled with $2 \mathrm{ml} \mathrm{EGM-2} \mathrm{media.} \mathrm{These} \mathrm{are} \mathrm{stromal} \mathrm{cells.}$

16. Alternatively, the Hem Pericytes can be plated on a non-coated dish in $10 \%$ FBS-DMEM as described in Boscolo et al., 2013.

F. Expanding bead-selected IH cells

1. Forty-eight hours after plating, carefully remove media and non-adherent cells with a pipette. Add fresh EGM-2 media into each well. You should see attached single cells and/or cell clusters.

2. Change the media every 2-3 days.

G. Passaging $\mathrm{IH}$-derived cells

1. To passage cells, first prepare $\mathrm{FN}$-coated plates at concentration $0.1 \mu \mathrm{g} / \mathrm{cm}^{2}$. Note: This is 10 fold lower than the amount of FN coated on plates used for the initial plating.

2. Wash plates with sterile PBS twice before use. The PBS from the 2nd wash should be removed right before the cells are ready to be plated.

3. Wash cell monolayer with PBS twice.

4. Aspirate PBS and add pre-warmed trypsin-EDTA $(0.8 \mathrm{ml} / \mathrm{p} 60,1.5 \mathrm{ml} / \mathrm{p} 100,5 \mathrm{ml} / \mathrm{p} 150)$. Gently rock the plates to evenly distribute the trypsin-EDTA.

5. Incubate in the $37^{\circ} \mathrm{C}$ incubator for $1-2 \mathrm{~min}$. Gently tap the plates to detach cells.

6. Inactivate the trypsin with quenching/thawing medium ( $5 \mathrm{ml} / \mathrm{p} 60,8 \mathrm{ml} / \mathrm{p} 100 ; 15 \mathrm{ml} / \mathrm{p} 150)$, transfer the trypsinized cells to a sterile tube. 
7. Recover remaining cells from the plate by adding quenching/thawing medium to rinse the plate. Collect the rinse and combine the cells into the same tube.

8. Determine cell number, centrifuge the cell suspension at $240 \times \mathrm{g}, \mathrm{RT}$ for $5 \mathrm{~min}$, and aspirate the supernatant.

9. Resuspend the cells in EGM-2 media and plate cells on a FN-coated, tissue culture-treated dish at a cell density 5,000 cells $/ \mathrm{cm}^{2}$ (sparse) or $10,000 \mathrm{cells} / \mathrm{cm}^{2}$.

a. HemSC, GLUT1-positive HemEC and HemPericyte are usually plated at 5,000 cells $/ \mathrm{cm}^{2}$. A $90 \%$ confluent $\mathrm{p} 100$ plate has $5 \times 10^{6}-6 \times 10^{6}$ cells.

b. GLUT1-negative HemEC are usually plated at $10,000 \mathrm{cells} / \mathrm{cm}^{2}$. A $90 \%$ confluent $\mathrm{p} 100$ plate has $3 \times 10^{6}-4 \times 10^{6}$ cells.

$\mathrm{H}$. Freezing $\mathrm{IH}$-derived cells

1. When cells are confluent, wash the monolayer twice with PBS.

2. Trypsinize the cells, collect the cell suspension and determine cell number.

3. Centrifuge cell suspension at $240 \times g$, RT for $5 \mathrm{~min}$.

4. Label a cryovial with the passage number $(+1)$, cell number, and date.

5. Suspend the cell pellet at $1 \times 10^{6}-5 \times 10^{6}$ cells in $1 \mathrm{ml}$ freezing medium and aliquot $0.5-1 \mathrm{ml}$ per cryovial.

6. Put cryovials into the "Mr. Frosty" and place at $-80{ }^{\circ} \mathrm{C}$ overnight.

7. The next day, move cryovials to the liquid nitrogen tank for long-term storage.

I. Thawing IH-derived cells

1. Prepare FN-coated, tissue culture-treated plates $\left(0.1 \mu \mathrm{g} / \mathrm{cm}^{2}\right)$, pre-warmed EGM2 medium and quenching/thawing medium.

2. Prepare $15 \mathrm{ml}$ Falcon tubes. Add $5 \mathrm{ml}$ quenching/thawing medium to each tube.

3. Wash FN-coated plates with PBS twice.

4. Quickly thaw frozen cells directly after removing from liquid nitrogen by placing in a $37^{\circ} \mathrm{C}$ water bath for 1-2 min. Gently swirl the tube to facilitate thawing.

5. Transfer cells into the $15 \mathrm{ml}$ tube pre-filled with quenching/thawing medium (avoid vigorous pipetting). Determine cell number.

6. Centrifuge cell suspension at $240 \times g$, RT for $5 \mathrm{~min}$.

7. Aspirate quenching/thawing medium. Resuspend cells in EGM-2 media and plate on FN-coated, tissue culture-treated dish ( $3 \mathrm{ml} / \mathrm{p} 60 ; 10 \mathrm{ml} / \mathrm{p} 100 ; 25 \mathrm{ml} / \mathrm{p} 150)$.

8. Label the coated plates with cell type, passage number, date, and initials.

9. Cells should attach within 4-6 $\mathrm{h}$ after plating. Add fresh media every 2-3 days.

\section{Data analysis}

Analyze cellular phenotype and purity by flow cytometry, immunofluorescence and qPCR at passage 
2-3. HemSC are positive for CD90 and VEGFR1 and negative for CD31 (Khan et al., 2008). GLUT1+ HemECs are initially positive for CD31, VE-cadherin and VEGFR2 by qPCR but with time in culture, these endothelial markers are no longer detected but instead the cells express the mesenchymal marker CD90 (see Huang et al., 2015). GLUT1-negative/CD31+ HemEC express CD31, VEcadherin and VEGFR2 and do not express CD90 (Huang et al., 2015), HemPericytes express PDGFRß, NG2, calponin, a-smooth muscle actin, NOTCH3 but not CD31 (Boscolo et al., 2013). Cells are re-analyzed as needed, for example before an in vivo experiment, to verify the phenotype. We typically use the cells between passages 4 and 10 .

\section{$\underline{\text { Notes }}$}

1. The percentage of $\mathrm{CD} 133^{+}$cells varies among different IH specimens (Yu et al., 2004).

2. The percentage of GLUT1 ${ }^{+}$endothelial cells is reduced in IH specimens from patients over one year of age (Huang et al., 2015).

3. $1 \%$ gelatin in PBS can be substituted for $\mathrm{FN}$ for coating the culture plates.

4. Always use freshly prepared EGM2-media to insure full and consistent activity of the growth factors in the Single Quots (VEGF-A, basic FGF, EGF and IGF1). Once the media is prepared it can be stored in working aliquots at $-20^{\circ} \mathrm{C}$ until use. Media stored at $2-8^{\circ} \mathrm{C}$ should be used within 3-4 days of preparation or thawing.

\section{$\underline{\text { Recipes }}$}

1. Heat inactivated FBS (hiFBS)

a. Thaw a $500 \mathrm{ml}$ bottle of HyClone FBS in warm water (for several hours) or at $4{ }^{\circ} \mathrm{C}$ overnight.

b. Put the thawed FBS into the $56{ }^{\circ} \mathrm{C}$ pre-heated water bath for 30 min (make sure the water covers all of FBS in the bottle. Mix the FBS in the bottle by shaking/inverting every $10 \mathrm{~min}$ to achieve an even temperature throughout the $500 \mathrm{ml}$ bottle.

c. Allow FBS to cool to room temperature.

d. Aliquot $45 \mathrm{ml}$ into sterile $50 \mathrm{ml}$ tubes and store in a $-20^{\circ} \mathrm{C}$ non-defrost freezer.

e. Thaw a $45 \mathrm{ml}$ frozen aliquot of heat-inactivated (hi)-FBS at $37^{\circ} \mathrm{C}$ for about $20 \mathrm{~min}$ or at $4{ }^{\circ} \mathrm{C}$ overnight before use.

2. Liberase ${ }^{\mathrm{TM}}$ Stock $(0.5 \mathrm{mg} / \mathrm{ml})$

$5 \mathrm{mg}$ lyophilized Liberase ${ }^{\mathrm{TM}}$

a. Dissolve in $10 \mathrm{ml}$ sterile $\mathrm{ddH}_{2} \mathrm{O}$

b. Make $0.5 \mathrm{ml}$ aliquots and store at $-20^{\circ} \mathrm{C}$

3. Dispase stock $(50 \mathrm{U} / \mathrm{ml}, 100 \mathrm{ml})$

Make $5 \mathrm{ml}$ aliquots and store at $-20^{\circ} \mathrm{C}$

4. $10 \times \mathrm{Ca}^{2+} / \mathrm{Mg}^{2+}$ solution, $500 \mathrm{ml}$

$927 \mathrm{mg} \mathrm{CaCl} 2 \cdot 2 \mathrm{H}_{2} \mathrm{O}$ (final concentration: $1.26 \mathrm{mM}$ ) 
$1.0 \mathrm{~g} \mathrm{MgSO}_{4} \cdot 7 \mathrm{H}_{2} \mathrm{O}$ (final concentration: $0.8 \mathrm{mM}$ )
a. Dissolve in sterile $\mathrm{ddH}_{2} \mathrm{O}$ to a final volume of $500 \mathrm{ml}$
b. Filter $(0.2 \mu \mathrm{m})$ and store at room temperature

5. Collection medium, $100 \mathrm{ml}$

$87 \mathrm{ml}$ DMEM (high glucose, GlutaMAX ${ }^{\mathrm{TM}}$ Supplement)

$10 \mathrm{ml} 10 \times \mathrm{Ca}^{2+} / \mathrm{Mg}^{2+}$ Solution

$2 \mathrm{ml} \mathrm{hi-FBS}$

$1 \mathrm{ml} 100 x$ GPS
a. Mix and filter $(0.2 \mu \mathrm{m})$
b. Aliquot to 5 or $10 \mathrm{ml} /$ tube and store at $-20{ }^{\circ} \mathrm{C}$ for up to 3 months

6. Digestion buffer, $6 \mathrm{ml}$ (make fresh)
a. Thaw $5 \mathrm{ml}$ Collection Medium
b. Add $0.5 \mathrm{ml}$ Liberase $^{\mathrm{TM}}(0.5 \mathrm{mg} / \mathrm{ml})$ (1:10; working concentration: $\left.50 \mu \mathrm{g} / \mathrm{ml}\right)$
c. Add $0.5 \mathrm{ml}$ Dispase $(50 \mathrm{U} / \mathrm{ml})(1: 10$; working concentration: $5 \mathrm{U} / \mathrm{ml})$

7. $6 \%$ ACD-A solution, $1 \mathrm{~L}$

\section{$22.3 \mathrm{~g}$ Glucose}

$22.0 \mathrm{~g}$ Sodium citrate

$8.0 \mathrm{~g}$ Citric acid

a. Dissolve in $\mathrm{ddH}_{2} \mathrm{O}$ to a final volume of $1 \mathrm{~L}$

b. Filter $(0.2 \mu \mathrm{m})$ and store at $4{ }^{\circ} \mathrm{C}$

8. Buffer A (PBS/0.6\% ACD-A/0.5\% BSA), $500 \mathrm{ml}$

\section{$2.5 \mathrm{~g} \mathrm{BSA}$}

$50 \mathrm{ml} 6 \%$ ACD-A solution

$450 \mathrm{ml}$ PBS

Dissolve, filter $(0.2 \mu \mathrm{m})$ and store at $4{ }^{\circ} \mathrm{C}$

9. Buffer $B(P B S / 0.6 \%$ ACD-A/0.1\% BSA), $500 \mathrm{ml}$

$0.5 \mathrm{~g} \mathrm{BSA}$

$50 \mathrm{ml} \%$ ACD-A solution

$450 \mathrm{ml}$ PBS

Dissolve, filter $(0.2 \mu \mathrm{m})$ and store at $4{ }^{\circ} \mathrm{C}$

10. EGM-2 Medium, $500 \mathrm{ml}$

$445 \mathrm{ml}$ EBM-2

$50 \mathrm{ml}$ hiFBS

$5 \mathrm{ml} 100 x$ GPS

EGM-2 Single Quot supplements (all except hydrocortisone)

Filter $(0.2 \mu \mathrm{m})$, aliquot $(45 \mathrm{ml} /$ tube $)$ and store at $-20^{\circ} \mathrm{C}$ until needed or store at $4{ }^{\circ} \mathrm{C}$ and use within 3-4 days

11. Fibronectin (FN)-coating buffer $\left(0.1 \mathrm{M} \mathrm{Na}_{2} \mathrm{CO}_{3}\right), 500 \mathrm{ml}$

$5.3 \mathrm{~g}$ of $\mathrm{Na}_{2} \mathrm{CO}_{3}$ 

a. Dissolve in $\mathrm{ddH}_{2} \mathrm{O}$ to a final volume of $500 \mathrm{ml}$
b. Adjust $\mathrm{pH}$ to 9.4 with $12 \mathrm{~N} \mathrm{HCl}$
c. Filter $(0.2 \mu \mathrm{m})$ and store at room temperature

12. Coating culture plates with fibronectin (FN)
a. Calculate the amount of FN needed; the stock is $1 \mu \mathrm{g} / \mu \mathrm{l}$
b. Use $1 \mu \mathrm{g} / \mathrm{cm}^{2}$ for freshly-isolated cells and $0.1 \mu \mathrm{g} / \mathrm{cm}^{2}$ for expansion of primary culture cells
c. Dilute FN into just enough FN-coating buffer to cover the plate(s)
d. Mix well and add to plates with a sterile pipette
e. Incubate in the $37^{\circ} \mathrm{C}$ incubator for 30 min or up to overnight (add more coating buffer for overnight incubation in case of evaporation)

13. Quenching/Thawing medium (500 ml)

$445 \mathrm{ml}$ DMEM (high glucose, GlutaMAX ${ }^{\mathrm{TM}}$ Supplement)

$50 \mathrm{ml}$ hiFBS (final 10\%)

$5 \mathrm{ml} 100 x$ GPS

Filter $(0.2 \mu \mathrm{m})$ and store at $4{ }^{\circ} \mathrm{C}$

EGM-2 media can also be used to quench but it is more expensive than DMEM

14. Freezing medium (make fresh)

$95 \%$ hiFBS

$5 \%$ DMSO

Filter $(0.2 \mu \mathrm{m})$ and store at $4{ }^{\circ} \mathrm{C}$

\section{Acknowledgments}

The development of the methods described in this manuscript was supported by the NHLBI of the National Institutes of Health under award number R01 HL096384 to J.B. The content is solely the responsibility of the authors and does not necessarily represent the official views of the National Institutes of Health.

\section{Competing interests}

The authors have no financial and non-financial competing interests to disclose.

\section{Ethics}

$\mathrm{IH}$ tissue used for these isolation procedures was obtained under an IRB-approved protocol from the Committee on Clinical Investigation at Boston Children's Hospital (04-12-175R; 11/11/2010 $6 / 6 / 2020)$. Informed consent was obtained from parents or guardians of the subjects. 


\section{References}

1. Boscolo, E. and Bischoff, J. (2009). Vasculogenesis in infantile hemangioma. Angiogenesis 12(2): 197-207.

2. Boscolo, E., Mulliken, J. B. and Bischoff, J. (2013). Pericytes from infantile hemangioma display proangiogenic properties and dysregulated angiopoietin-1. Arterioscler Thromb Vasc Biol 33: 501-509.

3. Boscolo, E., Coma, S., Luks, V. L., Greene, A. K., Klagsbrun, M., Warman, M. L. and Bischoff, J. (2015). AKT hyper-phosphorylation associated with PI3K mutations in Iymphatic endothelial cells from a patient with lymphatic malformation. Angiogenesis 18 (2): 151-162.

4. Couto, J. A., Huang, A. Y., Konczyk, D. J., Goss, J. A., Fishman, S. J., Mulliken, J. B., Warman, M. L. and Greene, A. K. (2017). Somatic MAP2K1 mutations are associated with extracranial arteriovenous malformation. Am J Hum Genet 100(3): 546-554.

5. Edwards, A. K., Glithero, K., Grzesik, P., Kitajewski, A. A., Munabi, N. C., Hardy, K., Tan, Q. K., Schonning, M., Kangsamaksin, T., Kitajewski, J. K., Shawber, C. J. and Wu, J. K. (2017). $\mathrm{NOTCH} 3$ regulates stem-to-mural cell differentiation in infantile hemangioma. JCl Insight 2(21).

6. Goines, J., Li, X., Cai, Y., Mobberley-Schuman, P., Metcalf, M., Fishman, S. J., Adams, D. M., Hammill, A. M. and Boscolo, E. (2018). A xenograft model for venous malformation. Angiogenesis 21(4): 725-735.

7. Greenberger, S., Boscolo, E., Adini, I., Mulliken, J. B. and Bischoff, J. (2010). Corticosteroid suppression of VEGF-A in infantile hemangioma-derived stem cells. N Engl J Med 362(11): 1005-1013.

8. Harbi, S., Wang, R., Gregory, M., Hanson, N., Kobylarz, K., Ryan, K., Deng, Y., Lopez, P., Chiriboga, L. and Mignatti, P. (2016). Infantile hemangioma originates from a dysregulated but not fully transformed multipotent stem cell. Sci Rep 6: 35811.

9. Huang, L., Couto, J. A., Pinto, A., Alexandrescu, S., Madsen, J. R., Greene, A. K., Sahin, M. and Bischoff, J. (2017). Somatic GNAQ mutation is enriched in brain endothelial cells in sturgeweber syndrome. Pediatr Neurol 67: 59-63.

10. Huang, L., Nakayama, H., Klagsbrun, M., Mulliken, J. B. and Bischoff, J. (2015). Glucose transporter 1-positive endothelial cells in infantile hemangioma exhibit features of facultative stem cells. Stem Cells 33(1): 133-145.

11. Itinteang, T., Vishvanath, A., Day, D. J. and Tan, S. T. (2011). Mesenchymal stem cells in infantile haemangioma. J Clin Pathol 64(3): 232-236.

12. Iwata, J., Sonobe, H., Furihata, M., Ido, E. and Ohtsuki, Y. (1996). High frequency of apoptosis in infantile capillary haemangioma. $J$ Pathol 179(4): 403-408.

13. Khan, Z. A., Boscolo, E., Picard, A., Psutka, S., Melero-Martin, J. M., Bartch, T. C., Mulliken, J. B. and Bischoff, J. (2008). Multipotential stem cells recapitulate human infantile hemangioma in immunodeficient mice. J Clin Invest 118(7): 2592-2599.

14. Leaute-Labreze, C., Harper, J. I. and Hoeger, P. H. (2017). Infantile haemangioma. Lancet 
390(10089): 85-94.

15. Mai, H. M., Zheng, J. W., Wang, Y. A., Yang, X. J., Zhou, Q., Qin, Z. P. and Li, K. L. (2013). $\underline{\mathrm{CD} 133}$ selected stem cells from proliferating infantile hemangioma and establishment of an in vivo mice model of hemangioma. Chin Med J (Engl) 126(1): 88-94.

16. Mancini, A. J. and Smoller, B. R. (1996). Proliferation and apoptosis within juvenile capillary hemangiomas. Am J Dermatopathol 18(5): 505-514.

17. Mulliken, J. B., Zetter, B. R. and Folkman, J. (1982). In vitro characteristics of endothelium from hemangiomas and vascular malformations. Surgery 92(2): 348-353.

18. Razon, M. J., Kraling, B. M., Mulliken, J. B. and Bischoff, J. (1998). Increased apoptosis coincides with onset of involution in infantile hemangioma. Microcirculation 5(2-3): 189-195.

19. Xu, D., O, T. M., Shartava, A., Fowles, T. C., Yang, J., Fink, L. M., Ward, D. C., Mihm, M. C., Waner, M. and Ma, Y. (2011). Isolation, characterization, and in vitro propagation of infantile hemangioma stem cells and an in vivo mouse model. J Hematol Oncol 4: 54.

20. Yu, Y., Flint, A. F., Mulliken, J. B., Wu, J. K. and Bischoff, J. (2004). Endothelial progenitor cells in infantile hemangioma. Blood 103(4): 1373-1375. 